\title{
Risk level Assessment of the Desalter and Preflash Column of a Nigerian Crude Distillation Unit
}

\author{
Henry 0. Orugba $^{*}{ }^{\circledR}$, Samuel E. Ogbeide ${ }^{1}$, Christian Osagie ${ }^{2}$ \\ ${ }^{1}$ Department of Chemical Engineering, University of Benin, Benin City, Nigeria \\ ${ }^{2}$ Faculty of Environmental and Natural Sciences, Brandenburg University of Technology, Cottbus, Germany \\ Email: ${ }^{*}$ orugbahenry@yahoo.com
}

How to cite this paper: Orugba, H.O., Ogbeide, S.E. and Osagie, C. (2019) Risk level Assessment of the Desalter and Preflash Column of a Nigerian Crude Distillation Unit. Journal of Materials Science and Chemical Engineering, 7, 31-41.

https://doi.org/10.4236/msce.2019.711004

Received: October 15, 2019

Accepted: November 25, 2019

Published: November 28, 2019

Copyright () 2019 by author(s) and Scientific Research Publishing Inc. This work is licensed under the Creative Commons Attribution International License (CC BY 4.0).

http://creativecommons.org/licenses/by/4.0/

\begin{abstract}
A study of operability and assessment of the safety level of a crude distillation unit in a Nigerian refinery has been carried out. In a crude distillation unit of a refinery, the desalter and preflash column, as well as their associated pipe works and pumps, are considered to have high-risk factors that can present operability problems and possibly hazardous conditions. Applying the HAZOP methodology, a total of 25 guide words were suitably applied on 4 nodes to study the possible deviations that may occur. The 89 causes of these deviations identified in the study could be classified under human errors and equipment malfunctioning. From the nature of the 46 consequences identified, the plant is likely to experience more of operability problems and less of deadly hazardous scenes. Suitable recommendations that will improve the operability and safety levels of the plant were however presented in the study and presented in tables. If the 61 recommendations given in this study can be incorporated into the design with the few safeguards already present in the original design of the plant, the operability problems of the plant will be greatly minimized and safety level will improve drastically.
\end{abstract}

\section{Keywords}

Hazard, Operability, HAZOP, Guide Word, Nodes, Refinery

\section{Introduction}

Building and operating a chemical plant without accident-preventive measures can cause an unquantifiable magnitude of hazards. Over the years, a good number of hazards have been recorded in the chemical industry around the world [1] 
and most of the recorded accidents were largely due to human error. The 1974 Flixborough disaster that was initiated by a reactor leak killed 28 persons, injured other 36 and destroyed properties [2]. The 1976 Seveso disaster led to the pollution of a vast area of land and water bodies. Thousands of people were killed and properties worth billions of dollars destroyed in the 1984 Bhopal disaster which was a direct consequence of human error [3]. Facilities worth billions of dollars were also destroyed in the 2005 Buncefield disaster while the 2010 BPL refinery disaster caused much pollution to water bodies [4]. The accidents that have occurred in the process industry have prompted owners and operators of modern day's chemical plants to incorporate safety measures to prevent accidents. The major industrial accidents recorded between 1956 and 1998 showed a decline in accidents in the chemical and process industries. This decline is traceable to the recent attention given to the study of accident forecasting and loss prevention in the chemical and process industries [5] [6]. Preventive-mechanism entails recognizing possible hazardous scenes within the plant which may vary in size and which may be noticeable or not noticeable [7]. Accident in the chemical and process industries can arise from the process itself, properties of the chemicals and their handling such as fire, explosion and exposure to toxic substances. For example, over temperature can lead to over pressure which can cause fire, explosion or toxic release that can cause accident. The predictions and prevention of accidents can be done by recognizing the hazards and the corresponding actions to be taken [8]. The use of certain process schemes or materials in production in order to maximize profit may result in operability problems and increase accident risks in the plant. For example, steam stripping is very effective in the vapourisation of more products in refineries [9] but due to cost of steam, some refiners have employed the use of water steam which is less expensive [10] [11] but with its associated hazards and operational problems.

Over the years, experts in process plant safety have developed risk-assessment procedures to enhance safety levels of process plants. Some of the many risk-assessment procedures developed so far include the Preliminary Hazard Assessment (PHA), the Fault Tree Analysis (FTA), the Energy Tree and Barrier Analysis (ETBA), the Failure Mode and Effects Analysis (FMEA) as well as the Hazard and Operability (HAZOP) [12]. Each of these mechanisms has strengths and weaknesses and is specialized in handling a particular type of risk. Although HAZOP is time-consuming as it requires a considerable amount of time of preparation, it gives a proper, organized and critical examination of the process of new or existing facilities to evaluate the potential for equipment malfunctioning in terms of the resultant impacts [13]. HAZOP performs a structural investigation of each unit in a process to depict what kind of deviation from the ideal operation can occur and what harm may be caused by such deviation. It is adopted in HAZOP study that a system is safe when key operability parameters such as temperature, pressure, flow or levels are in their normal conditions. Operability problems if not identified in HAZOP can result in production losses 
due to inferior product quality or process inefficiency. This means properly conducted HAZOP can help not just in plant and personnel safety but also prevents loss of continuity or loss of the product specification [14]. Initial HAZOP study helps identify suitable protection on measures that may be implemented to avoid impending accidents [5] [15]. HAZOP involves a study on how a plant might deviate from the intents while taking notes of the resulting appropriate solutions to these deviations. Since it is a group study, it creates a brainstorming environment that brings creativity and generates ideas. In HAZOP, a flow sheet on piping and instrumentation diagram (PID) for the plant is obtained. Each node on the PID is numbered where a series of disturbances are proposed. For each disturbance, potential causes and consequences are described and noted. Guide words are used to ensure that the design is explored in every conceivable way. It is paramount that a HAZOP team focuses only on consequences with serious effects since numerous consequences can be obtained. In this paper, the concept of HAZOP was applied to study the safety level of a crude distillation unit of a petroleum refinery.

\section{Description of the Facility}

Figure 1 shows the P \& ID of the desalter while Figure 2 shows the P \& ID of the preflash column of the refinery under study. The main units in the plant considered in this work are the desalter, the preflash furnace that uses fuel gas and fuel oil with medium steam and the preflash column as well as its associated pumps, controls and piping.

Crude from storage tank is pumped at $30^{\circ} \mathrm{C}$ and $30 \mathrm{~kg} / \mathrm{sqcm}$ through a valve into the first preheat train where its temperature is raised to about $125^{\circ} \mathrm{C}$ and pressure reduced to $11 \mathrm{~kg} / \mathrm{sqcm}$. Water is injected into the crude both at upstream and downstream of the first preheating train to dissolve salts contained in the crude. Water injection upstream of preheating is manually controlled at

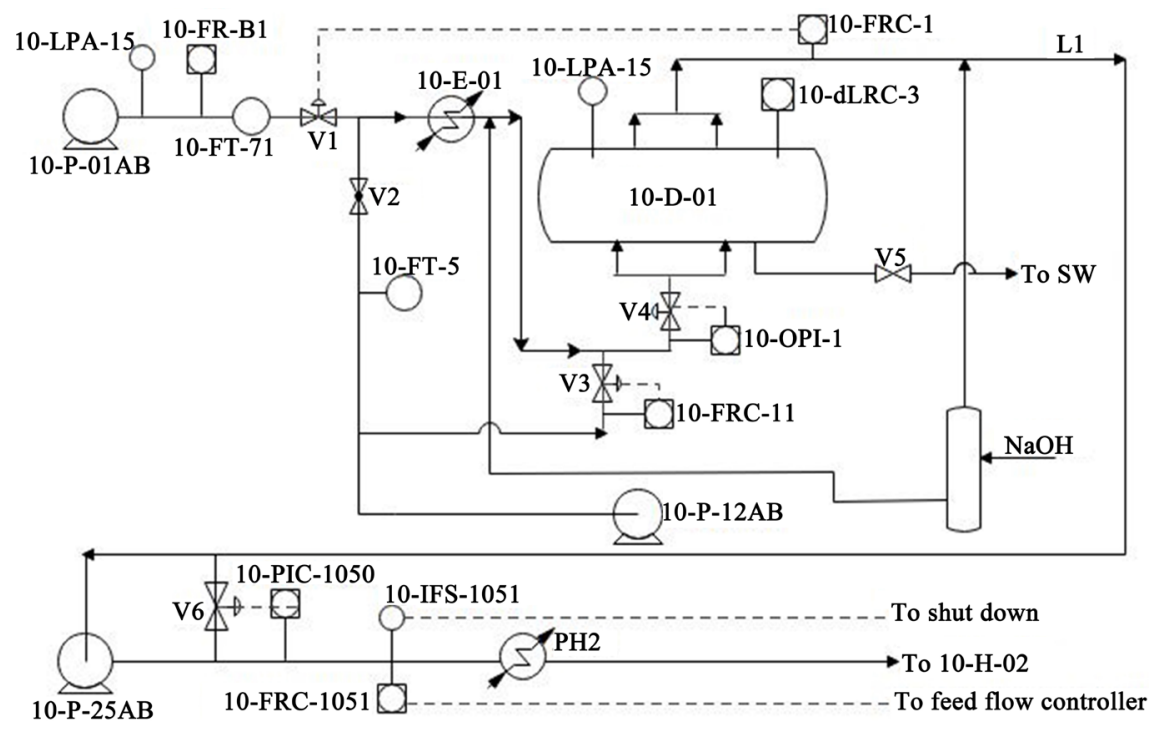

Figure 1. P \& ID of the Desalter and its associated pipe work. 


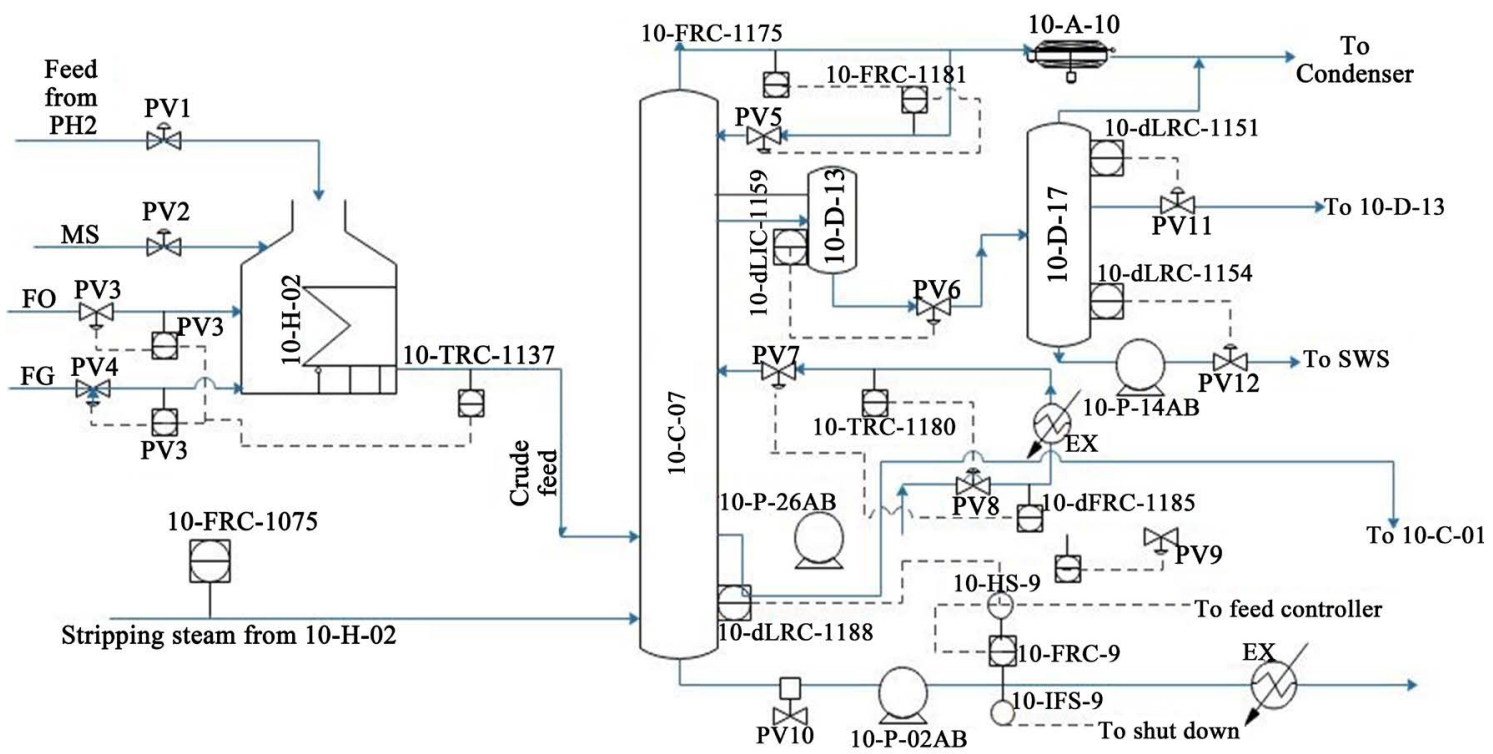

Figure 2. P \& ID of the Preflash distillation column and its associated pipe work.

$1 \%-1.5 \%$ volume of feed while downstream injection is controlled by a valve and kept at 3.5\% - 4\% volume of feed. If the desalter water is acidic, it enhances corrosion hence a $0.06 \%$ of $\mathrm{NaOH}$ is injected into the desalter water to keep its $\mathrm{pH}$ at 7.5 - 8.0. Demulsifier chemicals are injected at $3-5 \mathrm{ppm}$ of feed upstream of preheating to break oil/water emulsion and promote oil/water separation in the desalter.

Due to low velocity and long residence time, water can settle in the bottom of the desalter. Electrodes and electric grid are installed to generate an electric field in which water droplets too small to settle can electrically attract each other, coalesce in bigger drops and separate. Oil/water separation is also helped by demulsifier injection and significantly basic $\mathrm{pH}$ (caustic injection).

Downstream the first preheating train, crude flows through the mixing valve where mixing is promoted due to the pressure drop in the valve. Then the crude and water mixture enters the desalter and the salty water from the desalter bottom goes to waste water treatment unit while the desalted crude enters the second preheat before it proceeds to the preflash heater to raise its temperature up to the temperature required in the preflash column. The preflash heater uses fuel gas and fuel oil while atomizing steam is used to break up the fuel oil. The crude enters the preflash column and light fractions like LPG and light naphtha vapourized and are separated as overhead products, water and some hydrocarbons are withdrawn as side cuts while the crude heavier fractions remain in the bottom. Liquid fraction mainly heavy naphtha is also withdrawn as side cut and sent into the atmospheric column and the bottom sent to the atmospheric heater to raise its temperature to $350^{\circ} \mathrm{C}$ before it enters the atmospheric column flash zone.

\section{Methodology}

Selected lines and plant units in the P \& ID in Figure 1 and Figure 2 were ex- 
amined one after the other. For clarity, not all lines and units were considered in the study but only units like the desalter, the furnace and the preflash column as well as their associated pipe work that pose significant risks. Fouling and corrosion of equipment, increasing electrical conductivity of the crude oil, material losses, reduction in the efficiency of furnace and chocking of furnace tubes and flow lines are some of the major consequences that can arise from the malfunctioning of these selected units which can pose severe operability problems. Guide words were applied to each study node. In each node, a process parameter was identified and an intention was created for the node. For example, if the process parameter being considered was temperature, the first guide word like "low" was applied and a meaningful deviation like "low temperature" was developed. All the possible causes of low temperature as well as the likely consequences were determined. The study also identified existing operational safeguards but when a consequence is likely to pose a hazardous situation, recommendations were given for possible changes to be made to the system to eliminate or minimize hazard. The same process was carried out repeatedly for all the guide words on the same node. The next node was selected and the same activity was repeated on it.

\subsection{Guide Words}

The guide words used in the HAZOP study were as follows:

FLOW-high, low, no, reverse;

LEVEL-high, low;

PRESSURE-high, low;

TEMPERATURE-high, low;

CONTAMINANT.

\subsection{HAZOP Study of the Desalter}

The P \& ID of the desalter in Figure 1 was used to perform the HAZOP study and the details are presented in Table 1 and Table 2 as follows.

\subsection{HAZOP Study of the Preflash Column}

The P \& ID of the preflash column of the crude distillation unit in Figure 2 was used to perform the HAZOP study and the details are presented in Table 3 and Table 4 as follows:

\section{Results and Discussions}

The main equipment of the crude distillation unit of the refinery considered in this work was the desalter, the preflash furnace, the preflash column and their associated pipe works and equipment like pumps. Using the method of HAZOP to evaluate the operability and safety level of the unit, 4 study nodes were identified. In the study of possible deviations that can occur in the nodes, 25 guide words were suitably applied on the nodes and 89 causes were identified. Most of the causes were due to equipment malfunctioning and a few may be classified as 
Table 1. HAZOP minute sheet for the Crude Feed line and associated pipe work (Node 1).

\begin{tabular}{|c|c|c|c|c|}
\hline \multirow{2}{*}{\multicolumn{2}{|c|}{$\begin{array}{l}\text { Refining and Petrochemical Company } \\
\text { Project: Crude Distillation Unit }\end{array}$}} & & \multicolumn{2}{|c|}{ HAZOP Minute Sheet } \\
\hline & & & Node: 1 & Draw No:1 \\
\hline \multicolumn{5}{|c|}{ Node Description: Crude Feed Line and Associated Pipe Work } \\
\hline Guide Word & Cause & Consequence & Safeguards & Recommendation \\
\hline 1. High Flow & $\begin{array}{l}\text { 1. Crude feed pump 10-P-01AB increased } \\
\text { pumping capacity } \\
\text { 2. Low level alarm } 10 \text {-LPA- } 15 \text { faulty } \\
\text { 3. Crude feed flow regulator } 10 \text {-FR-BI faulty } \\
\text { 4. Valve V1 fully opened } \\
\text { 5. Water pump 10-P-12AB increased pumping } \\
\text { capacity } \\
\text { 6. Valve V2 fully opened } \\
\text { 7. Valve V3 fully opened } \\
\text { 8. Flow controller } 10 \text {-FRC-11 faulty }\end{array}$ & $\begin{array}{l}\text { 1. High ratio of crude to water } \\
\text { mixture causing low dissolution of } \\
\text { salt from crude oil } \\
\text { 2.Increased corrosion and fouling of } \\
\text { downstream equipment } \\
\text { 3. More water in oil-water mixture } \\
\text { causing increased crude } \\
\text { conductivity and trips off desalter } \\
\text { transformer }\end{array}$ & & $\begin{array}{l}\text { 1. Frequently check and maintain feed pump } \\
\text { 2. Check and maintain feed flow controller } \\
\text { 3. Frequent check and maintain water pump } \\
\text { 4. Frequent checking of all flow valves and } \\
\text { flow lines }\end{array}$ \\
\hline 2. Low Flow & $\begin{array}{l}\text { 1. Crude feed pump } 10-\mathrm{P}-01 \mathrm{AB} \text { fails } \\
\text { 2. Low level alarm } 10 \text {-LPA- } 15 \text { faulty } \\
\text { 3. Crude feed flow controller } 10 \text {-FR-BI faulty } \\
\text { 4. Valve V1 partially blocked } \\
\text { 5. Heat exchanger } 10 \text {-E- } 01 \text { tubes partially blocked } \\
\text { 6. Water pump 10-P-12AB fails } \\
\text { 7. Valve V2 partially blocked } \\
\text { 8. Valve V3 partially blocked } \\
\text { 9. Flow controller } 10 \text {-FRC-11 faulty }\end{array}$ & $\begin{array}{l}\text { 1. Low crude in oil-water mixture } \\
\text { increasing conductivity and } \\
\text { consequent tripping off of desalter } \\
\text { transformer } \\
\text { 2. Less water in oil-water mixture } \\
\text { causing poor salt dissolution } \\
\text { 3. Fouling and corrosion of } \\
\text { downstream equipment }\end{array}$ & $\begin{array}{l}\text { 1. Low level } \\
\text { alarm comes } \\
\text { up }\end{array}$ & $\begin{array}{l}\text { 1. Install spare crude feed pump to auto start } \\
\text { when feed pump fails } \\
\text { 2. Inspect and maintain crude feed flow } \\
\text { controller } \\
\text { 3. Inspect and maintain feed flow lines and } \\
\text { valves } \\
\text { 4. Frequent cleaning of heat exchangers tubes } \\
\text { 5. Install a spare water pump to auto start } \\
\text { when pump 10-P-12AB fails } \\
\text { 6. Check and maintain water flow controller } \\
\text { and valves }\end{array}$ \\
\hline 3. No Flow & $\begin{array}{l}\text { 1. Feed pump } 10-\mathrm{P}-01 \mathrm{AB} \text { faulty } \\
\text { 2. Valve V1 fully closed } \\
\text { 3. Heat exchanger } 10-\mathrm{E}-01 \text { tubes fully blocked }\end{array}$ & $\begin{array}{l}\text { 1. Desalter volume falls and crude oil } \\
\text { loss in effluent water }\end{array}$ & $\begin{array}{l}\text { 1. Low level } \\
\text { alarm } \\
\text { comes up }\end{array}$ & $\begin{array}{l}\text { 1. Regular checking and maintenance of feed } \\
\text { flow lines and valves } \\
\text { 2. Install a spare pump to auto start when } \\
\text { pump 10-P-12AB fails }\end{array}$ \\
\hline
\end{tabular}

Table 2. HAZOP Minute sheet for the Desalter and associated pipe work (Node 2).

\begin{tabular}{|c|c|c|c|c|}
\hline \multirow{2}{*}{\multicolumn{2}{|c|}{$\begin{array}{l}\text { Refining and Petrochemical Company } \\
\text { Project: Crude Distillation Unit }\end{array}$}} & \multicolumn{3}{|c|}{ HAZOP Minute Sheet } \\
\hline & & & Node: 2 & Draw No:1 \\
\hline \multicolumn{5}{|c|}{ Node Description: Desalter and Associated Pipe Work } \\
\hline Guide Word & Cause & Consequence & Safeguards & Recommendation \\
\hline 1. High Pressure & $\begin{array}{l}\text { 1. Automatic pressure controllers } 10-\mathrm{PRC}-1 \text { failed } \\
\text { 2. Discharge line L1 partially blocked causing low } \\
\text { discharge rate } \\
\text { 3. Low discharge rate of pump 10-P-25AB }\end{array}$ & $\begin{array}{l}\text { 1. Poor salt dissolution from the crude } \\
\text { 2. Formation of more stable oil-water } \\
\text { emulsion difficult to separate }\end{array}$ & $\begin{array}{l}\text { 1. Pressure safety } \\
\text { valve will pop } \\
\text { open and } \\
\text { transformer will } \\
\text { trip }\end{array}$ & $\begin{array}{l}\text { 1. Frequently check and maintain } \\
\text { pressure controller } \\
\text { 2. Install low pressure alarm } \\
\text { 3. Frequently check and maintain } \\
\text { flow lines and pumps }\end{array}$ \\
\hline 2. Low Pressure & 1. Automatic pressure controller 10-PRC-1 failed & $\begin{array}{l}\text { 1. Vapourisation of light ends from desalter } \\
\text { 2. Transformer trips off }\end{array}$ & & $\begin{array}{l}\text { 1. Frequently check and maintain } \\
\text { pressure controller }\end{array}$ \\
\hline $\begin{array}{l}\text { 3. High } \\
\text { Temperature }\end{array}$ & 1. High crude residence time in heat exchangers & 1. Loss of light ends from crude & & $\begin{array}{l}\text { 1. Install temperature regulator } \\
\text { 2. Install High temperature alarm }\end{array}$ \\
\hline $\begin{array}{l}\text { 4. Low } \\
\text { Temperature }\end{array}$ & $\begin{array}{l}\text { 1. Fouling of heat exchangers } \\
\text { 2. Preheat train network failed }\end{array}$ & $\begin{array}{l}\text { 1. Poor settling and oil loss in the } \\
\text { effluent water }\end{array}$ & & $\begin{array}{l}\text { 1. Install temperature regulator } \\
\text { 2. Install Low temperature alarm }\end{array}$ \\
\hline 5. High Level & $\begin{array}{l}\text { 1. Level controller } 10-\mathrm{dLRC}-3 \text { faulty } \\
\text { 2. Discharge pump } 10-\mathrm{P}-25 \mathrm{AB} \text { failed } \\
\text { 3. Waste water valve V5 blocked }\end{array}$ & $\begin{array}{l}\text { 1. Carryover of interface with oil into } \\
\text { tower causing fouling and corrosion } \\
\text { of downstream equipment } \\
\text { 2. Level rises to electrode causing } \\
\text { current flow and transformer trips }\end{array}$ & & $\begin{array}{l}\text { 1. Install high level alarm } \\
\text { 2. Frequently check and maintain } \\
\text { pumps and valves }\end{array}$ \\
\hline 6. Low Level & $\begin{array}{l}\text { 1. Level controller } 10 \text {-DLRC- } 3 \text { faulty } \\
\text { 2. Mixer valve V4 partly blocked }\end{array}$ & $\begin{array}{l}\text { 1. Carryover of crude with effluent } \\
\text { water }\end{array}$ & & $\begin{array}{l}\text { 1. Install low level alarm } \\
\text { 2. Check mixer valve }\end{array}$ \\
\hline
\end{tabular}


Table 3. HAZOP Minute sheet for the Preflash furnace (Node 3).

\begin{tabular}{|c|c|c|c|c|}
\hline \multirow{2}{*}{\multicolumn{2}{|c|}{$\begin{array}{l}\text { Refining and Petrochemical Company } \\
\text { Project: Crude Distillation Unit }\end{array}$}} & \multicolumn{3}{|c|}{ HAZOP Minute Sheet } \\
\hline & & & Node: 3 & Draw No:2 \\
\hline Guide Word & Cause & Consequence & Safeguards & Recommendation \\
\hline 1. High Flow of feed & $\begin{array}{l}\text { 1. Increased pumping capacity of feed } \\
\text { pump10-P- } 25 \mathrm{AB} \\
\text { 2. Crude feed line valve PV1 fully opene } \\
\text { 3. Crude feed flow controller } 10 \text {-FRC-1051 faulty }\end{array}$ & $\begin{array}{l}\text { 1. High level in preflash column causing } \\
\text { column offset } \\
\text { 2. Low temperature of preflash column } \\
\text { feed }\end{array}$ & & $\begin{array}{l}\text { 1. High flow alarm should be installed } \\
\text { 2. Frequent checking and } \\
\text { maintenance of flow controllers } \\
\text { and valves }\end{array}$ \\
\hline 2. Low Flow of feed & $\begin{array}{l}\text { 1. Low head of crude feed pump } 10-\mathrm{P}-25 \mathrm{AB} \\
\text { 2. Feed valve PV1 partly blocked } \\
\text { 3. Feed flow controller } 10-\mathrm{FRC}-1051 \text { failed } \\
\text { 4. Fouling of preflash furnace tubes } \\
\text { 5. Ruptured heater tubes }\end{array}$ & $\begin{array}{l}\text { 1. Low level in preflash column } \\
\text { 2. Pump cavitations and leaks }\end{array}$ & & $\begin{array}{l}\text { 1. Low flow alarm installation } \\
\text { suggested } \\
\text { 2. Check and clean furnace tubes } \\
\text { when choked with coke } \\
\text { 3. Regular checking and } \\
\text { maintenance of flow controller } \\
\text { and valves } \\
\text { 4. Clean heat exchangers tubes when } \\
\text { blocked }\end{array}$ \\
\hline 3. No Flow of feed & $\begin{array}{l}\text { 1. Pump 10-P-25AB fails } \\
\text { 2. Feed valve PV1 fully blocked } \\
\text { 3. Feed flow controller } 10-\text { FRC- } 1051 \text { faulty } \\
\text { 4. Fouling of preflash furnace tubes } \\
\text { 5. Ruptured heater tubes }\end{array}$ & $\begin{array}{l}\text { 1. Furnace pipe will be chocked with coke } \\
\text { 2. Low level in preflash column causing } \\
\text { pump cavitations and leaks }\end{array}$ & & $\begin{array}{l}\text { 1. Install spare feed pump to auto } \\
\text { start if pump 10-P-25AB fails } \\
\text { 2. Check and maintain flow } \\
\text { controller and valves regularly } \\
\text { 3. Inspect heat exchangers and flow } \\
\text { lines and clean them when dirty }\end{array}$ \\
\hline 4. High Flow of fuel & $\begin{array}{l}\text { 1. Temperature controller } 10-\text { TRC- } 1137 \text { faulty } \\
\text { 2. Fuel oil flow controller FR-1146 faulty } \\
\text { 3. Fuel gas flow controller FR-1149 faulty } \\
\text { 4. Fuel oil valve PV3 fully opened } \\
\text { 5. Fuel gas valve PV4 fully opened }\end{array}$ & $\begin{array}{l}\text { 1. Coking in furnace tubes } \\
\text { 2. Fouling of furnace tubes }\end{array}$ & & $\begin{array}{l}\text { 1. Regular inspection of fuel valve } \\
\text { and circulation system } \\
\text { 2. Check temperature controller } \\
\text { regularly }\end{array}$ \\
\hline 5. Low flow of fuel & $\begin{array}{l}\text { 1. Temperature controller } 10-\text { TRC- } 1137 \text { faulty } \\
\text { 2. Fuel oil flow controller FR-1146 faulty } \\
\text { 3. Fuel gas flow controller FR-1149 faulty } \\
\text { 4. Fuel oil valve PV3 partially blocked } \\
\text { 5. Fuel gas valve PV4 partially blocked }\end{array}$ & 1. Low coil outlet temperature & & $\begin{array}{l}\text { 1. Frequent inspection of fuel valves } \\
\text { 2. Check and maintain temperature } \\
\text { controller }\end{array}$ \\
\hline $\begin{array}{l}6 . \text { Low Flow of } \\
\text { atomizing steam }\end{array}$ & 1. Steam control valve PV2 faulty & $\begin{array}{l}\text { 1. Incomplete combustion } \\
\text { 2. Smoke generation }\end{array}$ & & $\begin{array}{l}\text { 1. Install steam-air ratio with low } \\
\text { steam rate alarm }\end{array}$ \\
\hline $\begin{array}{l}\text { 7. As well as High } \\
\text { Flow of primary air }\end{array}$ & 1. High draught & $\begin{array}{l}\text { 1. Increased stack loss } \\
\text { 2. Reduced furnace efficiency }\end{array}$ & & 1. Install air-fuel ratio controller \\
\hline $\begin{array}{l}\text { 8. As well as low } \\
\text { Flow of primary air }\end{array}$ & 1. Low draught & $\begin{array}{l}\text { 1. Incomplete combustion. } \\
\text { 2. Loss of fuel }\end{array}$ & & 1. Install air-fuel ratio controller \\
\hline $\begin{array}{l}\text { 9. High } \\
\text { Temperature }\end{array}$ & $\begin{array}{l}\text { 1. Furnace temperature controller } 10 \text {-TRC- } 1137 \\
\text { faulty } \\
\text { 2. Fuel oil flow controller FR-1146 faulty } \\
\text { 3. Fuel gas flow controller FR-1149 faulty } \\
\text { 4. Fuel oil valve PV3 fully opened } \\
\text { 5. Fuel gas valve PV4 fully opened }\end{array}$ & $\begin{array}{l}\text { 1. Cracking of crude feed } \\
\text { 2. High crude temperature may cause } \\
\text { pressure build up and rupture furnace } \\
\text { tubes }\end{array}$ & & $\begin{array}{l}\text { 1. Regular checking and } \\
\text { maintenance of heater } \\
\text { temperature controller } \\
\text { 2. Install high temperature alarm } \\
\text { 3. Frequent checking of heater fuel } \\
\text { valves }\end{array}$ \\
\hline $\begin{array}{l}\text { 10. Low } \\
\text { Temperature }\end{array}$ & $\begin{array}{l}\text { 1. Temperature controller } 10-\text { TRC- } 1137 \text { faulty } \\
\text { 2. Fuel oil flow controller FR-1146 faulty } \\
\text { 3. Fuel gas flow controller FR-1149 faulty } \\
\text { 4. Fuel oil valve PV3 partially blocked } \\
\text { 5. Fuel gas valve PV4 partially blocked } \\
\text { 6. Fouling in heater tubes }\end{array}$ & $\begin{array}{l}\text { 1. Low coil outlet temperature into } \\
\text { preflash column }\end{array}$ & & $\begin{array}{l}\text { 1. Regular check and maintain } \\
\text { temperature controllers } \\
\text { 2. Check fuel flow valves frequently. } \\
\text { 3. Inspect crude preheat train } \\
\text { regularly }\end{array}$ \\
\hline 11. High Pressure & $\begin{array}{l}\text { 1. High temperature in furnace causing release of } \\
\text { light ends }\end{array}$ & $\begin{array}{l}\text { 1. Expansion of hot oil and consequent } \\
\text { rupture of furnace tubes }\end{array}$ & & $\begin{array}{l}\text { 1. Install pressure controller } \\
\text { 2. Install high pressure alarm }\end{array}$ \\
\hline
\end{tabular}


Table 4. HAZOP Minute sheet for the Preflash column (Node 4)

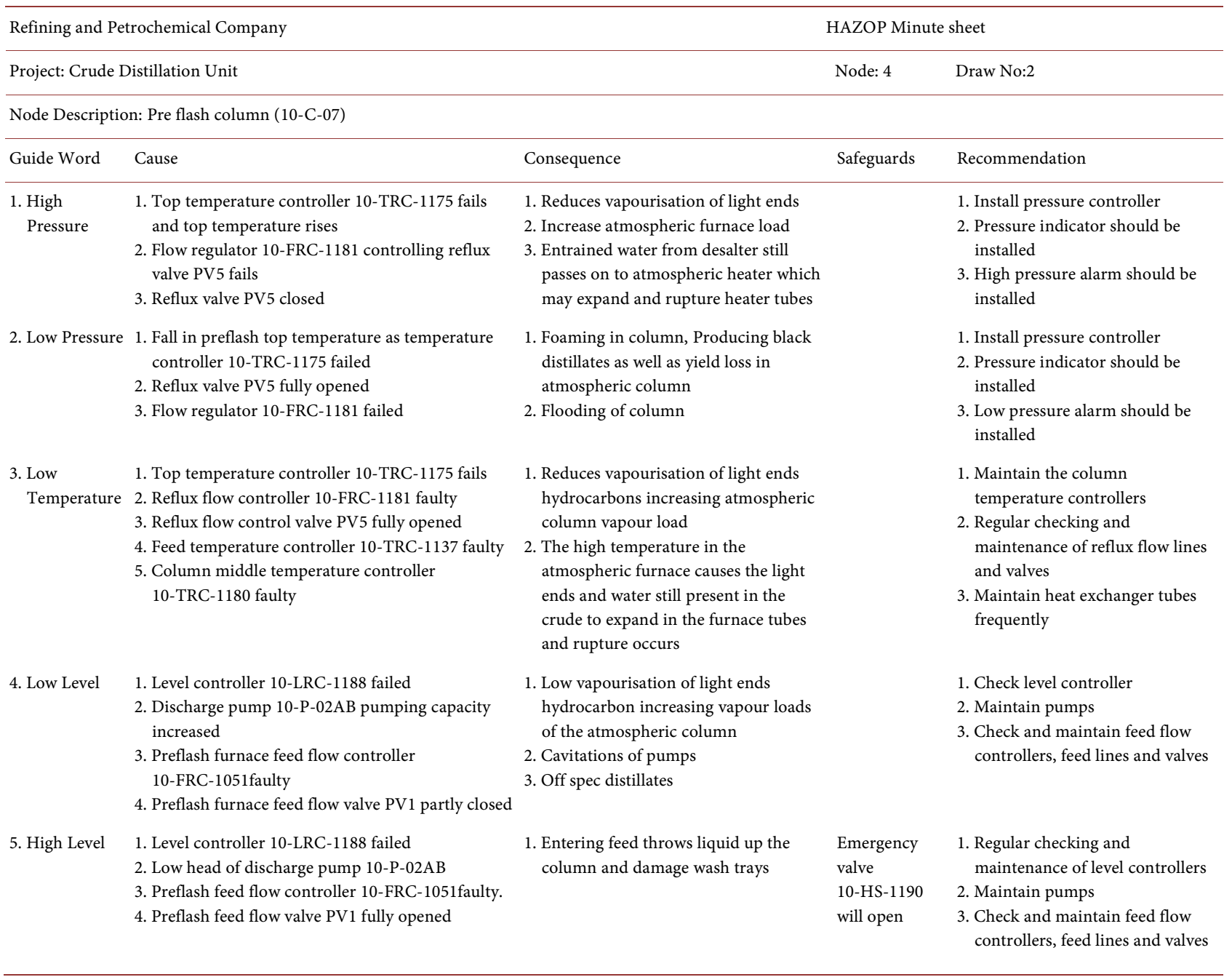

human error. These causes gave rise to 46 consequences. All the consequences can only pose operability problems that may lead to shut down but none of the consequences can really be termed as very hazardous and life-threatening. The plant can, therefore, be said to have a high safety level. This may be due to the existing safeguards designed into the plant. 61 recommendations were given in the study to further improve the operability and safety level of the plant.

\section{Conclusion}

Based on the nature of recommendations given in the HAZOP study, in order to prevent operability problems and hazardous conditions in the plant, there should be regular inspection; regular maintenance of flow lines and equipment and possibly replace faulty equipment. It is highly recommended that more safeguards be incorporated into the design to further improve the safety level of the plant. However, it is highly recommended that a thorough HAZOP study should preferably be carried out during the design phase of a plant so as to have much influence on the design. 


\section{Conflicts of Interest}

The authors declare no conflicts of interest regarding the publication of this paper.

\section{References}

[1] Goharrokhi, M. (2005) Hazard Identification by HAZOP method and Qualitative Risk Ananlysis in Process Industries. Daneshgaran Sanat Pajouh, Tehran, 67-72.

[2] Lees, F.P. (2005) Lee's Loss Prevention in the Process Industries: Hazard Identification, Assessment and Control. 3rd Edition, Elsevier, Oxford, UK.

[3] Abbasi, T. and Abbasi, S.A. (2005) The Expertise and the Practice of Loss Prevention in the Indian Process Industry. Process Safety and Environmental Protection, 83, 413-420. https://doi.org/10.1205/psep.04210

[4] Abbasi, T., Pompapathi, V., Tauseef, S.M. and Abbasi, S.A. (2017) An Assessment of the Prevailing Codes/Standards and Models for Determining Safe Spacing between Two or More Hazardous Storage Tanks. International Journal of Engineering, Science and Mathematics, 6, 255-268.

[5] Khan, F. and Abbasi, S. (1997) Mathematical Model for HAZOP Study Time Estimation. Journal of Loss Prevention in Process Industries, 10, 249-251. https://doi.org/10.1016/S0950-4230(97)00010-7

[6] Rigas, F. and Amyotte, P.R. (2013) Myths and Facts about Hydrogen Hazards. Chemical Engineering Transactions, 31, 913-918.

[7] Gholami, M. and Aryani, G. (2008) Safety Management and Hazards Identification methods and Consequences Analysis in the Oil, Gas and Petrochemical Industries. Oil National Company of Petrochemical Industries, First Congress of Safety Health, Bander Abbas, 28-35.

[8] Sedegheh, A., Shakiba, B., Mansour, Z. and Shirazeh, A. (2015) Comparison of Risk Assessment Using HAZOP and ETBA Techniques: Case Study of a Gasoline Refinery Unit in Iran. Journal of Human, Environment and Health Promotion, 1, 19-27.

[9] Mamdouh, G., Dina, K., Fatima, A. and Hemdan, N.E. (2013) A New Optimization Based Retrofit Approach for Revamping an Egyptian Crude Distillation Unit. Energy Procedia, 36, 454-464. https://doi.org/10.1016/j.egypro.2013.07.051

[10] Li, X.G., Lin, C.W., Wang, L. and Li, H. (2013) Exergy Analysis of Multi-Stage Crude Distillation Units. Frontiers of Chemical Science and Engineering, 7, 437-446. https://doi.org/10.1007/s11705-013-1349-y

[11] Samborskaya, M.A., Gusev, V.P., Gryaznova, J.A., Vdovushkina, N.S. and Volf, A.V. (2014) Crude Oil with Superheated Water Steam: Parametrical Sensitivity and Optimization. Procedia Chemistry, 10, 337-342. https://doi.org/10.1016/j.proche.2014.10.057

[12] Mohammadfam, I. and Kianfar, A. (2010) Application of Hazard and Operability Study (HAZOP) in Evaluation of Health, Safety and Environment (HSE) Hazards (Case Study: Oil Storage of National Iranian Oil Products Distribution Company). Journal of Environmental Science and Technology, 12, 39-49.

[13] Dunjo, J., Fthenakis, R., Dabra, R., Vichez, J. and Arnaldos, J. (2011) Conducting HAZOPs in Contimous Chemical Processes: Part I. Criterial, Tools and Guidelines for Selecting Nodes. Process Safety and Environmental Protection, 89, 224-233. https://doi.org/10.1016/j.psep.2011.03.002

[14] Sikandar, S., Ishtiaque, S. and Soomro, N. (2016) Hazard and Operability (HAZOP) 
Study of Waste Water Treatment Unit Producing Biohydrogen. Sidh University Research Journal (Science Series), 48, 131-136.

[15] Ashok, S. and Prakas, J. (2014) HAZOP Study of Sewage Treatment Plant at Educational Institution. International Journal Research of Engineering Technology, 3, 2319-2321. 


\section{Nomenclature}

\begin{tabular}{|c|c|}
\hline $10-\mathrm{C}-07$ & Preflash column \\
\hline $10-\mathrm{D}-01$ & Desalter \\
\hline 10-dLRC-3 & Desalter level controller \\
\hline $10-\mathrm{E}-01$ & Heat exchanger 01 \\
\hline 10-FR-B1 & Flow regulator in crude feed line to desalter \\
\hline 10-FRC-1051 & Flow regulator controlling preflash furnace crude feed \\
\hline 10-FRC-1075 & Flow regulating flow of preflash column bottom steam \\
\hline 10-FRC-11 & Desalter water flow controller regulator \\
\hline 10-FRC-1181 & Preflash column reflux flow controller \\
\hline $10-\mathrm{H}-02$ & Preflash furnace \\
\hline 10-IFS-1051 & Flow controller to shut down \\
\hline 10-LPA-15 & Low pressure alarm in crude feed line to desalter \\
\hline 10-LRC-1188 & Level regulator in preflash column \\
\hline $10-\mathrm{P}-01 \mathrm{AB}$ & Crude storage pump \\
\hline $10-\mathrm{P}-02 \mathrm{AB}$ & Discharge pump from preflash bottom \\
\hline $10-\mathrm{P}-12 \mathrm{AB}$ & Pump supplying desalter water \\
\hline $10-\mathrm{P}-25 \mathrm{AB}$ & Desalted crude discharge pump \\
\hline $10-\mathrm{P}-26 \mathrm{AB}$ & Preflash column pumparound pump \\
\hline 10-PRC-1 & Desalter pressure controller \\
\hline 10-PRC-IV & Pressure controller in crude feed line to desalter \\
\hline 10-TRC-1137 & Preflash coil out temperature regulator \\
\hline 10-TRC-1175 & Preflash column top temperature controller \\
\hline FR-1146 & Preflash furnace fuel oil flow regulator \\
\hline FR-1149 & Preflash furnace fuel gas flow regulator \\
\hline L1 & Desalted crude flow line from desalter \\
\hline MPA & Middle pumparound \\
\hline PH1 & First preheat train \\
\hline $\mathrm{PH} 2$ & Second preheat train \\
\hline PV10 & Emergency valve in preflash bottom \\
\hline PV2 & Control valve in preflash furnace medium steam supply line \\
\hline PV3 & Control valve in preflash furnace fuel oil supply line \\
\hline PV4 & Control valve in preflash furnace fuel gas supply line \\
\hline PV5 & Preflash column reflux control valve \\
\hline PV7 & Control valve regulating flow from preflash pump around into preflash column \\
\hline PV8 & Control valve regulating temperature in preflash pump around \\
\hline PVI & Control valve in preflash furnace crude feed line \\
\hline SS & Stripping steam \\
\hline SW & Sore water \\
\hline V1 & Control valve in crude feed line to desalter \\
\hline $\mathrm{V} 2$ & Flow valve in upstream desalter water feed line \\
\hline V3 & Control valve regulating downstream desalter water \\
\hline V4 & Desalter mix valve \\
\hline V5 & Valve in sore water flow line \\
\hline
\end{tabular}

